\title{
Pro-apoptotic activity of novel synthetic isoxazole derivatives exhibiting inhibitory activity against tumor cell growth in vitro
}

\author{
ILARIA LAMPRONTI ${ }^{1}$, DANIELE SIMONI ${ }^{2}$, RICCARDO RONDANIN ${ }^{2}$, \\ RICCARDO BARUCHELLO ${ }^{2}$, CHIARA SCAPOLI $^{1}$, ALESSIA FINOTTI $^{1}$, \\ MONICA BORGATTI $^{1,3}$, CHIARA TUPINI $^{1}$ and ROBERTO GAMBARI ${ }^{1}$ \\ Departments of ${ }^{1}$ Life Sciences and Biotechnology, and ${ }^{2}$ Chemical and Pharmaceutical Sciences; \\ ${ }^{3}$ Center of Biotechnology, Ferrara University, I-44121 Ferrara, Italy
}

Received September 20, 2019; Accepted June 1, 2020

DOI: $10.3892 / \mathrm{ol} .2020 .12002$

\begin{abstract}
In order to develop potential anticancer agents stimulating apoptosis, novel 3,4-isoxazolediamide and 4,5,6,7-tetrahydro-isoxazolo-[4,5-c]-pyridine derivatives have been synthetized. The original structures of geldanamycin and radicicol, which are known natural heat shock protein (HSP) inhibitors, were deeply modified because both of them exhibit several drawbacks, such as poor solubility, hepatotoxicity, intrinsic chemical instability or deprivation of the in vivo activity. This novel class of synthetic compounds containing the isoxazole nucleus exhibited potent and selective inhibition of HSP90 in previous studies. Biological assays (focusing on in vitro antiproliferative effects and pro-apoptotic activity) in human erythroleukemic K562 cells (as a model system referring to tumor cells grown in suspension), glioblastoma U251-MG and glioblastoma temozolomide (TMZ)-resistant T98G cell lines (two model systems referring to tumor cells grown attached to the flask), were performed. Almost all isoxazole derivatives demonstrated significant antiproliferative and pro-apoptotic activities, showing induction of both early and late apoptosis of K562 cells. Different effects were observed on the glioma U251-MG and T98G cells, depending on the structure of the analogues. Antiproliferative and pro-apoptotic activities in K562 cells were associated with the activation of the erythroid differentiation program. The present study demonstrated that 3,4-isoxazolediamide and 4,5,6,7-tetrahydro-isoxazolo-[4,5-c]-pyridine derivatives
\end{abstract}

Correspondence to: Professor Roberto Gambari, Department of Life Sciences and Biotechnology, Ferrara University, Via L. Borsari 46, I-44121 Ferrara, Italy

E-mail: gam@unife.it

Abbreviations: TMZ, temozolomide; HSPs, heat shock proteins; DMSO, dimethyl sulfoxide; EtOH, ethanol; PS, phosphatidyl serine; CML, chronic myelogenous leukemia

Key words: heat shock protein inhibitors, cancer, glioblastoma, K562 cells, U251-MG cells, T98G cells, apoptosis, caspases should be considered for in vivo studies focusing on the development of anticancer drugs acting, at least partially, via activation of apoptosis.

\section{Introduction}

The protein synthesis is a very complex process involved in cell growth, differentiation and survival. Molecular chaperones, such as heat shock proteins (HSPs), are key elements in these biological processes, helping the polypeptide folding involved in reaching functional conformation, as well as facilitating the protein stability, trafficking and proteolytic turnover (1).

HSPs are present in almost all living organisms and their expression is increased in response to different physical, chemical and biological insults, including temperature, presence of heavy metals and oxidative stress (2). Most of the elements inducing cellular stress might cause protein denaturation and must be reduced or eliminated with the help of molecular chaperones. In the process of cell senescence and in several diseases a defective chaperone function was noted $(1,2)$. If cellular stress proceeds unchecked by the common mechanisms of action regulated by chaperones, intracellular proteins become denatured and insoluble, and then precipitates as aggregates. The development of inclusion bodies is, for instance, a usual pathological process in several disorders, even in the absence of cellular stress (2). Drugs able to modulate the heat shock response and induce HSP expression might have a potential therapeutic value. In neoplastic cells, HSPs (mainly HSP90) are often overexpressed. As reported by Garcia-Carbonero and collaborators, the oncogenic potential of cells is dependent on their ability to survive despite endogenous (hypoxia, $\mathrm{pH}$ changes, nutrient deprivation, dysregulated signaling pathways) and exogenous (radiation or chemotherapy) insults (3). Moreover, increased HSP expression may stabilize oncogenic proteins and promote independence of growth factors, cancer-cell survival, proliferation, immortalization, neo-vascularization and metastasis (3).

HSP90 is constitutively expressed in normal cells, representing $1-2 \%$ of the total intracellular protein. Since in neoplastic cells, its levels increase to 4-6\% (4), HSP90 has thus emerged as significant target in several diseases and, in particular, being a protein with the ability to act as regulator 
on tumor cell cycle progression, it is considered a remarkable therapeutic target for anticancer drug development. Therefore, the interest for new possible HSP90 inhibitors is intensified (5).

With the identification of this interesting new target, pure natural molecules isolated from plants and other natural organisms have been found to be an important source of new HSP90 inhibitors, with the potential of being of interest for the future development of novel selective anticancer agents (6).

Geldanamycin and radicicol are natural products to inhibit the HSP90 activity. In the past, studies on the natural antibiotic geldanamycin demonstrated that this benzoquinone ansamycin exhibits potent antitumor activity against human cancer cells (7), but unfortunately its therapeutic usage has been limited, due to its poor water solubility and severe hepatotoxicity. Recently, the chemical structure of geldanamycin has been modified with the aim to reduce toxicity issues and to increase its water-solubility. The position 17 of the benzoquinone group represents the modified moiety to generate new derivatives, including 17-allylamino-, 17-demethoxy geldanamycin (17-AAG) and 17-N,N-dimethylaminoethylamino-17-dimethoxy geldanamycin (17-DMAG), studied in phase II/III or I in clinical trials, respectively (8).

Radicicol (9), the second mentioned natural active agent, is a macrocyclic anti-fungal antibiotic, also able to inhibit HSP90 activity by interacting with the same site of action of geldanamycin $(9,10)$. However, due to its intrinsic chemical instability, it displayed very limited in vivo effects.

Starting from these and other known natural molecules, many synthetic efforts have been described in literature to obtain other Hsp90 inhibitors with better features. Some of them reported the 1,3-dihydroxybenzene (resorcinol ring, present also in radicicol structure) bound to a pyrazole or isoxazole ring as an important scaffold for very active molecules, such as the drug candidate NVP-AUY922 (Luminespib) (11).

Some other synthetic compounds, including the derivatives used in the present study and containing an isoxazole nucleus, have recently shown potent and selective inhibition of HSP90 (12,13). The presence of the heterocyclic nucleus seems to exert an important role in the docking of these derivatives to the ATP-binding site of HSP90 (14).

We $(12,13)$ and other research groups $(11,14)$ have studied new resorcinol structurally related molecules. Our novel synthetized inhibitors of HSP90 (compounds 1-8, Fig. 1) $(12,13)$, investigated in the present work, are characterized by modifications on the isoxazole scaffold focusing mainly on the $\mathrm{C}-4$ position, by introducing of a second amide group to ameliorate the protein interaction, producing an extra interaction with Lys58, as well as a concomitant reorientation of the aromatic portion. The key interactions of the $\mathrm{OH}$-resorcinol (1,3-dihydroxybenzene) groups and the C-3 amide still remain identical in the series of 3,4-isoxazolediamides (12).

The other series here reported is represented by 4,5,6,7-tetrahydro-isoxazolo-[4,5-c]-pyridine analogues (compounds 9-13, Fig. 2), containing a condensed bicyclic group. Also, in this series, the resorcinol portion was maintained because of its importance and role in the interaction with the HSP90 protein. However, structural alterations and substitution of the resorcinol group were investigated (13).

The first aim of the present study was to determine whether these new derivatives exhibit antiproliferative effects on the
K562 human experimental cellular system (15). This model system was selected in consideration of the fact that it has been proposed as very useful for the screening of antitumor compounds, and that undergoes terminal differentiation when exposed to some antitumor drugs $(16,17)$. Since inhibitory effects of tumor cell growth might be associated to activation of early and late apoptosis, the second and more general aim was to investigate the possible pro-apoptotic effect of these compounds on K562 human leukemia cells and on two additional cell lines representative of solid tumors, the glioblastoma U251-MG and T98G cell lines. It should be underlined that comparing glioblastoma cell lines which respond (the U251-MG) or not (the T98G) to temozolomide (TMZ) treatment is very important, since glioblastoma multiforme (VI grade tumor) is one of the most aggressive solid tumors and TMZ chemotherapy, while remaining the most commonly used clinical treatment, cannot be proposed in TMZ resistant tumors (18).

\section{Materials and methods}

Chemical compounds.3,4-isoxazolediamides and 4,5,6,7-tetrahydro-isoxazolo-[4,5-c]-pyridine derivatives were synthesized as reported in Baruchello et al $(12,13)$. Compounds 1-8 were synthesized as described in ref. 12. Compounds 9-11 were synthesized as described in ref. 13. Compounds 12 and 13 were obtained similarly as described in ref. 13. For characterization of the compounds, $1 \mathrm{H}-\mathrm{NMR}$ data were recorded at $200 \mathrm{MHz}$ on a Bruker AC 200 spectrometer. Electrospray mass analyses were recorded on a double focusing Finnigan MAT 95 instrument with BE geometry. Melting points were determined on a Reichter-Kofler apparatus. HPLC analysis were performed with a Jupiter column $100 \times 4.6 \mathrm{~mm}, 5 \mu \mathrm{m} \mathrm{C}_{18}$, $1 \mathrm{ml} / \mathrm{min}$ flow, $\mathrm{H}_{2} \mathrm{O}+0.1 \%$ TFA/Acetonitrile $+0.1 \%$ TFA, $\mathrm{T}_{0} 95 / 5 \%, \mathrm{~T}_{25} 0 / 100 \%$, UV detector $220 \mathrm{~nm}$. Combustion analysis of all the compounds is compatible with a purity $>95 \%$. The compounds 1-13 were solubilized in dimethyl sulfoxide (DMSO) and further dilutions ( $1 \mathrm{mM}-1 \mu \mathrm{M})$ were made with ethanol (EtOH). The stock solutions (10-50 mM) were stored at $-20^{\circ} \mathrm{C}$ and thawed just before the treatment.

Cell cultures. Human erythroleukemic K562 cells are a human immortalized myelogenous leukemia cell line isolated and characterized by Lozzio CB and Lozzio BB, from a patient with chronic myelogenous leukemia (CML) in blast crisis (19,20). U251-MG glioma cells (Sigma-Aldrich; Merck KGaA) are derived from a male patient with malignant astrocytoma and they represent an important biological model to study genetic aberrations and molecular pathways in a complex tumor such as glioblastoma (21). The T98G cell line (Sigma-Aldrich; Merck KGaA) was derived from a glioblastoma multiforme tumor of a Caucasian male (18). K562, U215 and T98G cells were cultured in humidified atmosphere of $5 \% \mathrm{CO}_{2}$, in RPMI-1640 medium (Lonza) supplemented with $10 \%$ fetal bovine serum filtered $0.2 \mu \mathrm{M}$ (FBS; Biowest, Nuaillè, France), $50 \mathrm{U} / \mathrm{ml}$ penicillin (Lonza) and $50 \mu \mathrm{g} / \mathrm{ml}$ streptomycin (Lonza). Cell viability of control untreated cells was always $>95 \%$, based on trypan-blue exclusion tests and on the FACS analyses presented in Figs. 3-6. 


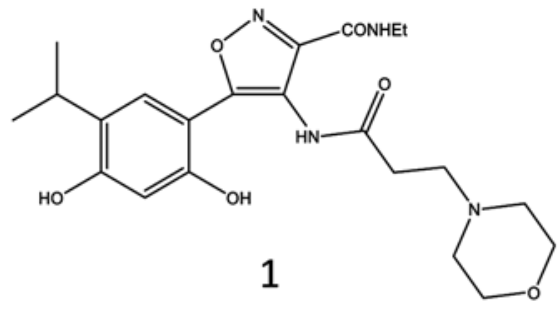<smiles>CCOc1noc(-c2cc(C(C)C)c(O)cc2O)c1NC(=O)c1ccc(OC)cc1</smiles><smiles>CCOc1noc(-c2cc(C(C)C)c(O)cc2O)c1NC(=O)C(C)(C)C</smiles>

3<smiles>CCOc1noc(-c2cc(C(C)C)c(O)cc2O)c1NC(=O)c1cc(C(C)=O)on1</smiles><smiles>CCOc1noc(-c2cc(C(C)C)c(C)cc2O)c1NC(C)=O</smiles>

4<smiles>CCOc1noc(-c2cc(C(C)C)c(O)cc2O)c1NC(=O)c1sccc1C</smiles>

5

Figure 1. Chemical structures of compounds 1-8 (3,4-isoxazolediamides) analyzed in the present study.<smiles>COc1noc2c1CN(C(=O)c1cc(C(C)C)c(O)cc1O)CC2</smiles>

9<smiles>COc1ccc(C(=O)Nc2c(OC)noc2-c2cc(Cl)c(O)cc2O)cc1OC</smiles>

7<smiles>COc1ccc(C(=O)Nc2c(OC)noc2-c2cc(Cl)c(O)cc2O)cc1</smiles>

8<smiles>COc1noc2c1CN(C(=O)c1ccc(O)cc1O)CC2</smiles>

10<smiles>COc1noc2c1CN(Cc1cc(Cl)c(O)cc1O)CC2</smiles>

11<smiles>COc1noc2c1CN(C(=O)c1ccc(N)c(O)c1)CC2</smiles>

12<smiles>CCOc1noc2c1CN(C(=O)c1cc(CN3CCOCC3)on1)CC2</smiles>

13

Figure 2. Chemical structures of compounds 9-13 (4,5,6,7-tetrahydro-isoxazolo-[4,5-c]-pyridines) analyzed in the present study.

Antiproliferative activity. The cells are counted with the Beckman Coulter ${ }^{\circledR}$ Z2 (Beckman Coulter, Inc.) to evaluate the possible antiproliferative effect caused by the compounds 1-13 after 72 and $96 \mathrm{~h}$ from the treatment, when they are in the log phase of growth. Preliminary tests were done to identify the
$\mathrm{IC}_{50}$ on $\mathrm{K} 562$ cells: 25,000 cells $/ \mathrm{ml}$ were seeded in 24 -well plates and treated with 3,4-isoxazolediamides and 4,5,6,7-tetrahydro-isoxazolo-[4,5-c]-pyridine compounds at different concentrations. Preliminary tests were done using large-scale concentrations $(1 \mathrm{nM}, 10 \mathrm{nM}, 100 \mathrm{nM}, 1 \mu \mathrm{M}, 10 \mu \mathrm{M}, 100 \mu \mathrm{M}$ 

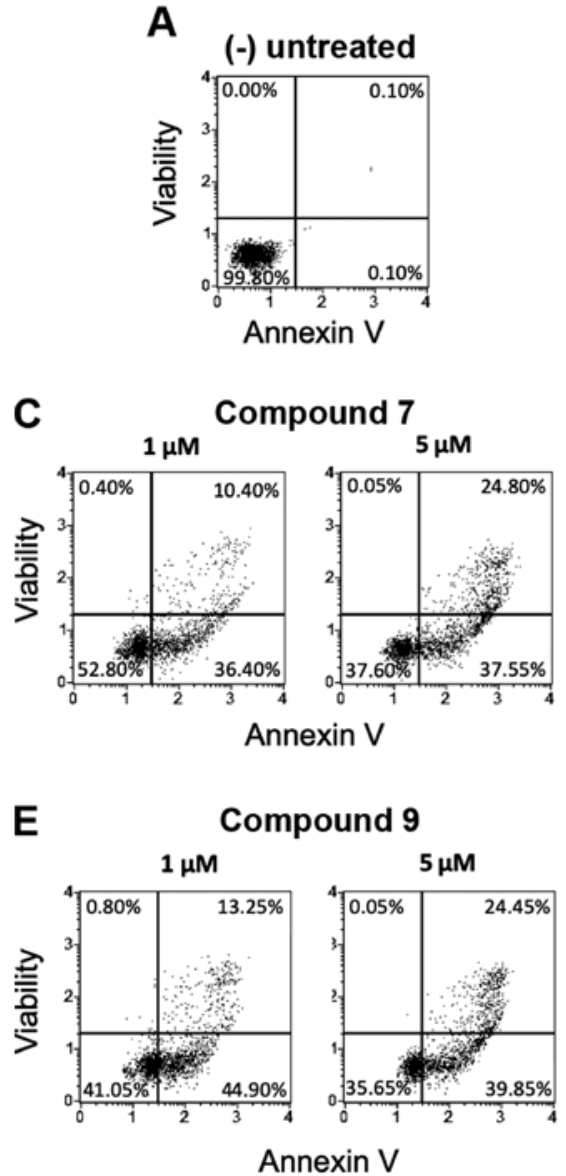
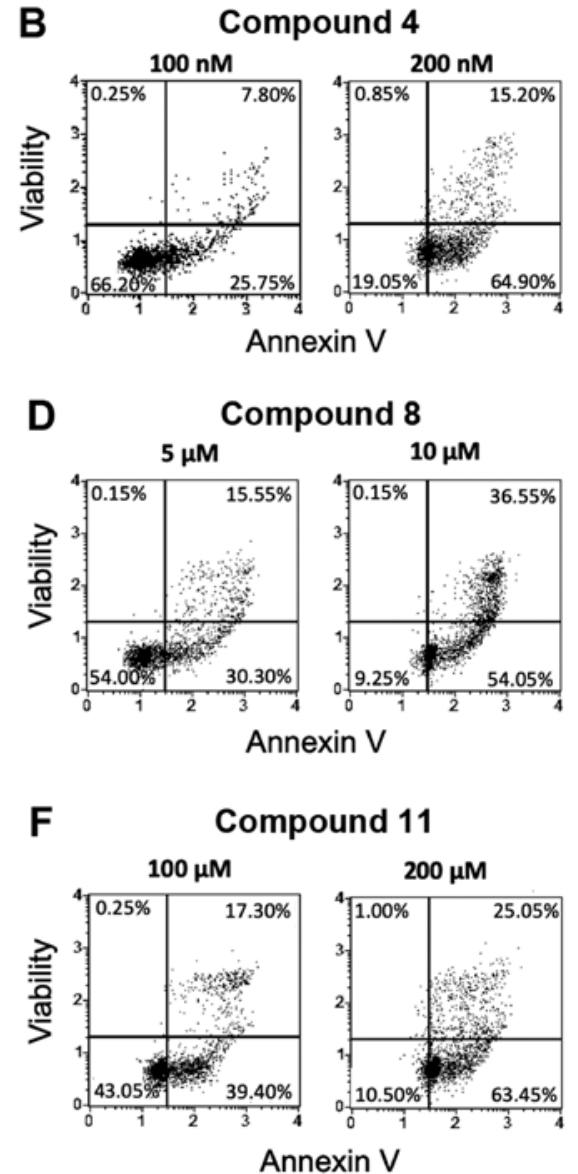

Figure 3. Effects of synthetic isoxazole derivatives on apoptosis of K562 cells. (A) Control untreated K562 cells. Representative examples of the effects of compounds (B) 4, (C) 7, (D) 8, (E) 9 and (F) 11, according to the Annexin-V assay performed on K562 cells treated for $72 \mathrm{~h}$ with two different concentrations of each isoxazole derivative. The complete set of data is shown in Table II.

and $300 \mu \mathrm{M}$ ) in order to identify the $\mathrm{IC}_{50}$ values on $\mathrm{K} 562$ cell line, and then experiments were made with selected concentrations near the $\mathrm{IC}_{50}$ found concentrations. All the experiments were repeated at least three times, independently.

Pro-apoptotic assay. K562, U251-MG and T98G cell lines were treated with two specific concentrations, both close to the $\mathrm{IC}_{50}$ values, previously determinated, in order to study the apoptotic effects of the derivatives. Annexin V and Dead Cell assays on all the used cell lines, untreated and treated with increasing doses of the selected isoxazole derivatives 1-11, were performed with the Muse cell analyzer (EMD Millipore), according to the instructions supplied by the manufacturer. This procedure utilizes Annexin V to detect phosphatidyl serine (PS) on the external membrane of apoptotic cells. Four populations of cells can be distinguished using this assay: live, early apoptotic, late apoptotic and dead cells. The MUSE cell analyzer is able to discriminate 'early' from 'late' apoptosis since 'early apoptotic cells' are Annexin V positive, and 7-AAD negative, while 'late apoptotic cells' are positive to both Annexin V and 7-AAD. Cells were washed with sterile $1 \mathrm{X}$ PBS, tripsinized, resuspended in the original medium and diluted (1:2) with the one step addition of the Muse Annexin V \& Dead Cell reagent. After incubation of $20 \mathrm{~min}$ at room temperature, samples were analyzed, using Triton X $0.01 \%$, as positive control (22). Triton X was employed in order to obtain a complete destruction of the cell membrane leading, following the MUSE analysis a very high death pattern. Data are acquired and recorded utilizing the Annexin V and Dead Cell Software Module (EMD Millipore). Caspase 3/7 activity was also analyzed on T98G cell line with the Muse cell analyzer (EMD Millipore), according to the instructions supplied by the manufacturer. After treatment with isoxazoles, cells were harvested, lysed and centrifuged. The Muse ${ }^{\mathrm{TM}}$ Caspase 3/7 is a non-toxic cell membrane permeable reagent; it contains a DNA binding dye that is linked to an amino acid sequence Asp-Glu-Val-Asp (DEVD) substrate. Cleavage by active Caspase $3 / 7$ of the DEVD peptide substrate in the cell results in release of the dye, translocation to the nucleus and binding of the dye to DNA with high fluorescence emission. A dead cell marker, 7-AAD (7-aminoactinomycin D), is also included in both the Annexin V and Caspase 4/7 assays as an indicator of cell membrane structural integrity and cell death. It is excluded from live, healthy cells, as well as early apoptotic cells, but permeates later stage apoptotic and dead cells. With this assay the percentage of cells that are live, dead, in the early and late stages of apoptosis can be detected. Control experiments demonstrated that no effects of the solvents used was observed at the maximum concentrations used (data not shown).

Induction of differentiation. K562 cells grow in culture as single, undifferentiated, cells in suspension, with low basal 
A

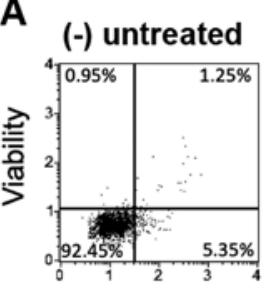

Annexin V

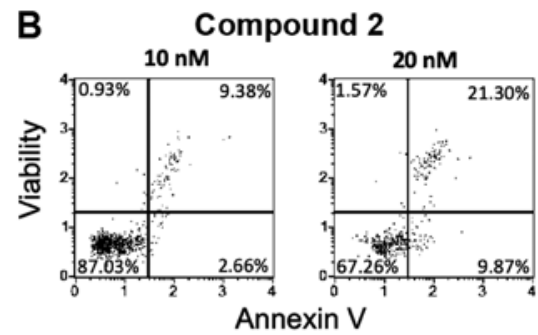

C

Compound 3

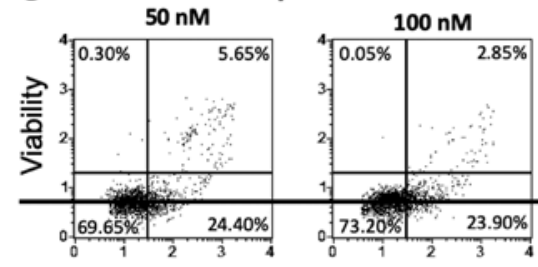

Annexin V

\section{Compound 4}

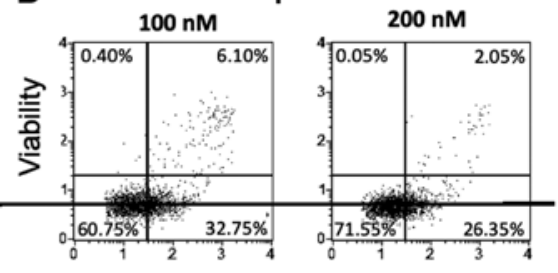

E

Compound 5
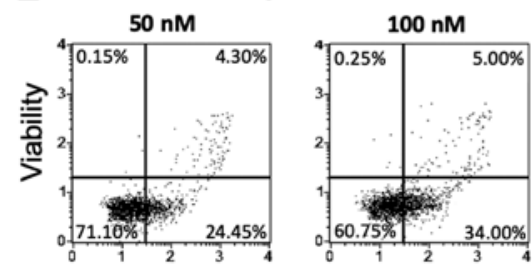

Annexin V

$\mathbf{F}$

Annexin V

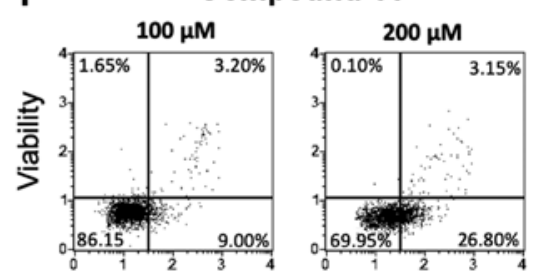

Annexin V

Figure 4. Effects of synthetic isoxazole derivatives on apoptosis of U251-MG cells. (A) Control untreated U251-MG cells. Representative examples of the effects of compounds (B) 2, (C) 3, (D) 4, (E) 5 and (F) 11, according the Annexin-V assay performed on U251-MG cells treated for $72 \mathrm{~h}$ with two different concentrations of each isoxazole derivative. The complete set of data is shown in Table III.
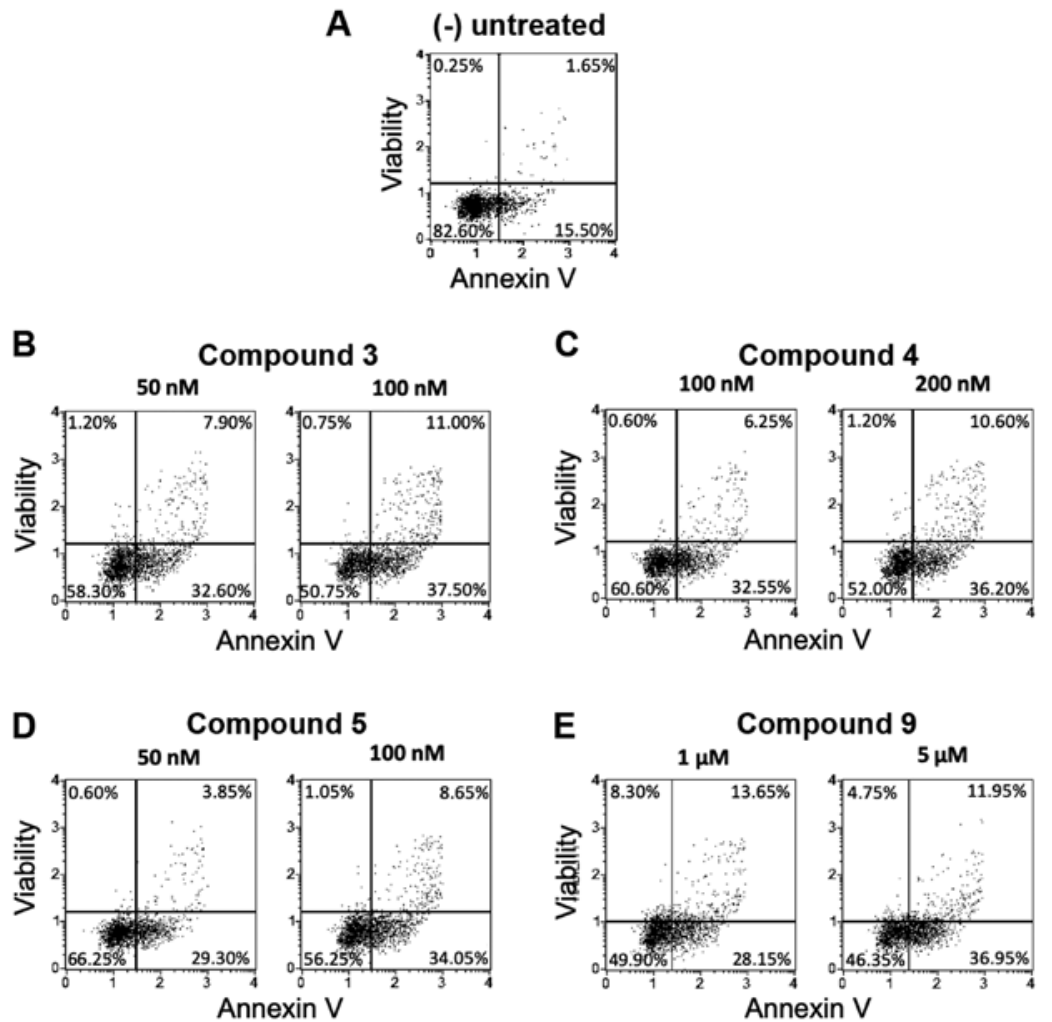

Figure 5. Effects of synthetic isoxazole derivatives on apoptosis of T98G cells. (A) Control untreated T98G cells. Representative examples of the effects of compounds (B) 3, (C) 4, (D) 5 and (E) 9 in the Annexin-V assay performed on T98G cells treated for $72 \mathrm{~h}$ with two different concentrations of each isoxazole derivative. The complete set of data is shown in Table IV. 


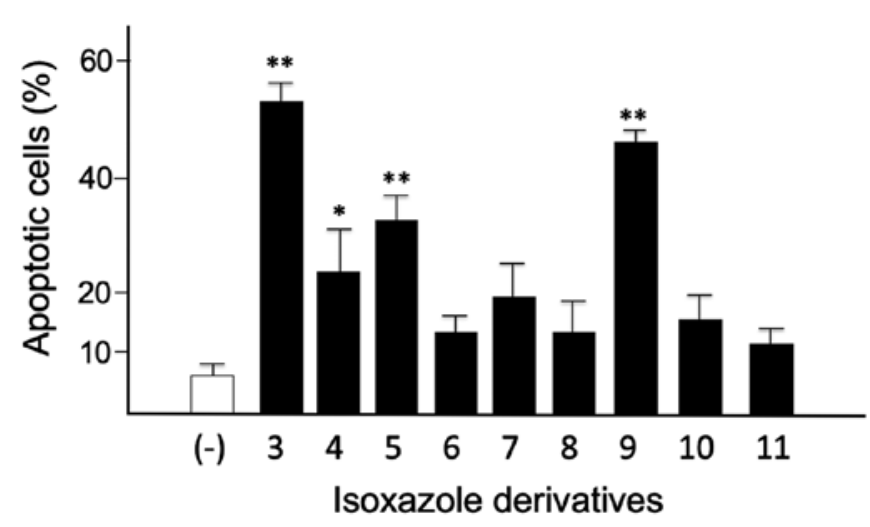

Figure 6. Percentage of apoptotic cells analyzed using the caspase 3/7 kit assay in T98G cells treated for $72 \mathrm{~h}$ with 3,4-isoxazolediamides and 4,5,6,7-tetrahydro-isoxazolo-[4,5-c]-pyridines derivatives 3-11. Results are presented as the mean \pm SEM $(n=3)$. ${ }^{*} \mathrm{P}<0.05$ and ${ }^{* *} \mathrm{P}<0.01$ vs. control untreated cells. (-), control untreated cells.

production of hemoglobin. As several antitumor compounds exert their action through activation of differentiated functions (17), erythroid differentiation was assayed on K562 cell cultures after 5-7 days of treatment (when K562 cells are in the plateau phase of cell growth) by counting benzidine $/ \mathrm{H}_{2} \mathrm{O}_{2}$ positive cells in a solution containing $0.2 \%$ benzidine in $5 \mathrm{M}$ glacial acetic acid, $10 \% \mathrm{H}_{2} \mathrm{O}_{2}$ as described elsewhere $(23,24)$.

Statistical analysis. In order to detect significance of the observed effects, results have been expressed as mean \pm standard errors (SEM) and comparison among groups was made by using analysis of variances (ANOVA) with Dunnett's test for comparison with a single control, and with Tukey's test for complete post hoc test. Statistical significance was defined as significant $(" \mathrm{P}<0.05)$ and highly significant $\left({ }^{* *} \mathrm{P}<0.01\right)$.

\section{Results}

Antiproliferative effects of 3,4-isoxazolediamides and 4,5,6,7-tetrahydro-isoxazolo-[4,5-c]-pyridines derivatives on the K562 cell line. The antiproliferative effects of the tested compounds were first evaluated on the human myelogenous leukemia K562 cell line. The cell count was performed after 72 and $96 \mathrm{~h}$ of cell culture, when cells are in the log phase of growth. Table I indicates the antiproliferative effects $\left(\mathrm{IC}_{50}\right.$ values, i.e., the inhibitory concentration required for obtaining 50\% cell growth inhibition) of all the tested compounds 1-13 (the experiments were repeated at least three times in the presence of the same experimental condition).

The obtained results indicate that, while two compounds (i.e. 12 and 13) are inactive at the used concentrations $\left(\mathrm{IC}_{50}>300 \mu \mathrm{M}\right)$, some derivatives show strong effects in inhibiting the in vitro proliferation of K562 cells. This is particularly remarkable for the compounds $1(71.57 \pm 4.89 \mathrm{nM})$, $2(18.01 \pm 0.69 \mathrm{nM}), 3(44.25 \pm 10.9 \mathrm{nM}), 4(70.1 \pm 5.8 \mathrm{nM})$, $5(35.2 \pm 6.2 \mathrm{nM}), 6(45.43 \pm 13.1 \mathrm{nM})$ and $10(68.3 \pm 5.2 \mu \mathrm{M})$ (for all of these compounds $\mathrm{P}<0.05$ with respect to control untreated cells).

Apoptosis analysis on K562, U251-MG and T98G cell lines was performed using compounds $1-11$, selected on the basis of their antiproliferative activity on K562 cells (Table I).
Table I. Antiproliferative effects in terms of $\mathrm{IC}_{50}$ of isoxazoles 1-13 on K562 cells.

\begin{tabular}{lc}
\hline Isoxazole derivative & $\mathrm{IC}_{50}$ of $\mathrm{K} 562$ cells \\
\hline 1 & $71.57 \pm 4.89 \mathrm{nM}$ \\
2 & $18.01 \pm 0.69 \mathrm{nM}$ \\
3 & $44.25 \pm 10.90 \mathrm{nM}$ \\
4 & $70.12 \pm 5.80 \mathrm{nM}$ \\
5 & $35.21 \pm 6.20 \mathrm{nM}$ \\
6 & $45.43 \pm 13.10 \mathrm{nM}$ \\
7 & $779.40 \pm 151.00 \mathrm{nM}$ \\
8 & $3.20 \pm 1.10 \mu \mathrm{M}$ \\
9 & $627.30 \pm 49.00 \mathrm{nM}$ \\
10 & $68.30 \pm 5.20 \mu \mathrm{M}$ \\
11 & $220.70 \pm 23.00 \mu \mathrm{M}$ \\
12 & $>300 \mu \mathrm{M}$ \\
13 & $>300 \mu \mathrm{M}$ \\
\hline
\end{tabular}

Derivatives 12 and 13 were not considered, being not active even when $300 \mu \mathrm{M}$ concentration was used (Table I). The pro-apoptosis assays were conducted at two concentrations approaching the $\mathrm{IC}_{50}$ values shown in Table I for K562 cells and preliminarily verified for $\mathrm{U} 251-\mathrm{MG}$ and T98G cells (data not shown). Representative data obtained from the analysis of the corresponding Muse Analyzer plots after $72 \mathrm{~h}$ from the treatment are shown in Figs. 3-5. The summaries of the data obtained with all the selected 1-11 compounds are shown in Tables II-IV.

Pro-apoptotic activity of 3,4-isoxazolediamides and 4,5,6,7-tetrahydro-isoxazolo-[4,5-c]-pyridines derivatives on K562 cells. Analysis of apoptosis on K562 cells treated with the studied isoxazoles was performed using the Annexin V release assay. Representative results are shown in Fig. 3.

Table II shows the complete set of results obtained studying the pro-apoptotic effects of these compounds in early and late apoptosis stage, compared to the untreated cells (negative control). These data were obtained from the analysis of the Muse Analyzer plots, after $72 \mathrm{~h}$ from the treatment (see Fig. 3 for representative examples).

Among the tested compounds, all were found to possess the ability to induce apoptosis on K562 cells, but the highest effects were found using the isoxazoles 4, 7, 8, 9 and 11. This remarkable biological activity is demonstrated by the fact that induced apoptosis was found in $>50 \%$ of the cells. In fact, the derivatives $4(100 \mathrm{nM}), 8(10 \mu \mathrm{M})$ and $11(200 \mu \mathrm{M})$ displayed high levels of apoptotic effect $(80.10,90.60$ and $88.50 \%$, respectively) with a relevant dose-depending increase. Also compound 2, 6 and 10 were found pro-apoptotic, but mainly at the highest concentrations used.

Pro-apoptotic activity on U251-MG and T98G glioma cells. Apoptosis analysis on both U251-MG and T98G cell lines was obtained by performing treatments with the same compounds previously analyzed on the K562 cell line. The following Figs. 4 and 5 (including representative experiments) and 
Table II. Pro-apoptotic activity of isoxazole derivatives 1-11 in K562 cells.

\begin{tabular}{|c|c|c|c|}
\hline Sample & Early apoptosis,\% & Late apoptosis,$\%$ & Total apoptosis, $\%$ \\
\hline Untreated cells (-) & 0.10 & 0.10 & 0.20 \\
\hline $1(50 \mathrm{nM})$ & 14.00 & 27.21 & 41.21 \\
\hline $1(100 \mathrm{nM})$ & 16.15 & 30.30 & 46.45 \\
\hline $2(10 \mathrm{nM})$ & 4.15 & 2.15 & 6.30 \\
\hline $2(20 \mathrm{nM})$ & 20.46 & 10.26 & 30.72 \\
\hline $3(50 \mathrm{nM})$ & 29.45 & 6.70 & 36.15 \\
\hline $3(100 \mathrm{nM})$ & 28.75 & 10.00 & 38.75 \\
\hline $4(100 \mathrm{nM})$ & 25.75 & 7.80 & 33.55 \\
\hline $4(200 \mathrm{nM})$ & 64.90 & 15.20 & 80.10 \\
\hline $5(50 \mathrm{nM})$ & 23.60 & 6.60 & 30.20 \\
\hline $5(100 \mathrm{nM})$ & 31.90 & 11.95 & 43.85 \\
\hline $6(50 \mathrm{nM})$ & 30.30 & 6.40 & 36.70 \\
\hline $6(100 \mathrm{nM})$ & 25.85 & 16.00 & 41.85 \\
\hline $7(1 \mu \mathrm{M})$ & 36.40 & 10.40 & 46.80 \\
\hline $7(5 \mu \mathrm{M})$ & 37.55 & 24.80 & 62.35 \\
\hline $8(5 \mu \mathrm{M})$ & 30.30 & 15.55 & 45.85 \\
\hline $8(10 \mu \mathrm{M})$ & 54.05 & 36.55 & 90.60 \\
\hline $9(1 \mu \mathrm{M})$ & 44.90 & 13.25 & 58.15 \\
\hline $9(5 \mu \mathrm{M})$ & 39.85 & 24.45 & 64.30 \\
\hline $10(50 \mu \mathrm{M})$ & 15.40 & 2.70 & 18.10 \\
\hline $10(100 \mu \mathrm{M})$ & 23.75 & 16.70 & 40.45 \\
\hline $11(100 \mu \mathrm{M})$ & 39.40 & 17.30 & 56.70 \\
\hline $11(200 \mu \mathrm{M})$ & 63.45 & 25.05 & 88.50 \\
\hline
\end{tabular}

Tables III and IV (including the full sets of data) show the results obtained, focusing on the effects of these isoxazoles on the cells in early and late apoptosis stage.

As we can observe in the Annexin $\mathrm{V}$ assay reported in Figs. 4 and 5 and in Tables III and IV, the isoxazoles derivatives have been able to induce significant percentages of apoptosis in both the glioblastoma cell lines, but with lower levels of total apoptosis when comparison was done with the data obtained using K562 cells. We reported in Fig. 4 the derivatives exhibiting the best activity on U251-MG cells (the derivatives 2, 3, 4,5 and 11, showing total apoptosis values $>30 \%$ ). In Fig. 5 the effects of the most active compounds on the TMZ-resistant T98G cells were reported (isoxazoles 3, 4, 5 and 9, showing total apoptosis values $>40 \%$ ). It should be noted that in the TMZ-resistant T98G cell line the trend of apoptosis induction is in general better than that observed using the same compounds on U251-MG cells, since different derivatives (for instance compounds 3, 4, 5, 9 and 10) showed higher activity when used on the TMZ-resistant cell model. In particular, the isoxazole 3 showed very high induction of apoptosis (48.50\%) at the concentration of $100 \mathrm{nM}$, while in U251-MG cells the obtained activity was $25.75 \%$. Furthermore, the compound 9 (used at 1 and $5 \mu \mathrm{M}$ ) induced the highest percentage of apoptosis in T98G cells (41.80 and $48.90 \%$, respectively), while in U251-MG cells the apoptosis induction efficiency was 20.90 and $28.40 \%$, respectively. Compounds 6,7 and 8 displayed low pro-apoptotic activities $(<25 \%$ at the highest concentration employed) on both glioma cells lines.
Caspase-mediated pro-apoptotic effects of compounds representative of the 3,4-isoxazolediamides and 4,5,6,7-tetrahydro-isoxazolo-[4,5-c]-pyridines structures on T98G glioma cell line. The Caspase $3 / 7$ assay was performed to further confirm the pro-apoptotic effects (25) of isoxazoles derivatives 3-11 at the concentration that produced the best results with the Annexin $\mathrm{V}$ assay (Table IV). In particular, the effects have been studied on the T98G glioma cells, since these cells are resistant to induction of apoptosis caused by TMZ, commonly used to treat glioblastoma patients) (10). The caspases 3 and 7 are effector caspases of the enzymatic cascade of activation of the apoptotic process. For this reason, they are considered biomarkers that indicate cells in the stages of the programmed death process. The data obtained are comparatively depicted in Fig. 6 as 'percentage of apoptotic cells' and include cells that are both in the early and late stages of the apoptotic process.

In summary, the one-way ANOVA confirmed that all compounds were able to induce an increase of apoptosis, being some derivatives more effective (particularly the isoxazoles 3 and 9, showing an apoptotic effect of 52.48 \pm 2.11 and 46.08 $48 \pm 1.49 \%$, respectively). This effect was highly significant (Dunnett's test $\mathrm{P}<0.0001, \mathrm{P}<0.0001$ and $\mathrm{P}<0.0083$, respectively) for isoxazole 3,9 and 5 with respect to control untreated cells.

Differentiation induced by isoxazole derivatives on the K562 cell line. When stimulated by various antitumor agents 
Table III. Pro-apoptotic activity of isoxazole derivatives 1-11 in U251-MG cells.

\begin{tabular}{|c|c|c|c|}
\hline Samples & Early apoptosis,\% & Late apoptosis $\%$ & Total apoptosis, $\%$ \\
\hline Untreated cells (-) & 5.35 & 1.25 & 6.60 \\
\hline $1(50 \mathrm{nM})$ & 5.04 & 14.15 & 19.19 \\
\hline $1(100 \mathrm{nM})$ & 7.71 & 21.37 & 29.08 \\
\hline $2(10 \mathrm{nM})$ & 2.66 & 9.38 & 12.04 \\
\hline $2(20 \mathrm{nM})$ & 9.87 & 21.30 & 31.17 \\
\hline $3(50 \mathrm{nM})$ & 24.40 & 5.65 & 30.05 \\
\hline $3(100 \mathrm{nM})$ & 23.90 & 2.85 & 26.75 \\
\hline $4(100 \mathrm{nM})$ & 32.75 & 6.10 & 38.85 \\
\hline $4(200 \mathrm{nM})$ & 26.75 & 2.05 & 28.40 \\
\hline $5(50 \mathrm{nM})$ & 24.45 & 4.30 & 28.75 \\
\hline $5(100 \mathrm{nM})$ & 34.00 & 5.00 & 39.00 \\
\hline $6(50 \mathrm{nM})$ & 11.95 & 2.25 & 14.20 \\
\hline $6(100 \mathrm{nM})$ & 14.85 & 1.95 & 16.80 \\
\hline $7(1 \mu \mathrm{M})$ & 6.45 & 1.60 & 8.05 \\
\hline $7(5 \mu \mathrm{M})$ & 13.15 & 1.95 & 15.10 \\
\hline $8(5 \mu \mathrm{M})$ & 7.00 & 3.50 & 10.50 \\
\hline $8(10 \mu \mathrm{M})$ & 7.95 & 1.40 & 9.35 \\
\hline $9(1 \mu \mathrm{M})$ & 19.15 & 1.75 & 20.90 \\
\hline $9(5 \mu \mathrm{M})$ & 23.95 & 4.45 & 28.40 \\
\hline $10(50 \mu \mathrm{M})$ & 5.70 & 1.95 & 7.65 \\
\hline $10(100 \mu \mathrm{M})$ & 6.80 & 3.30 & 10.10 \\
\hline $11(100 \mu \mathrm{M})$ & 9.00 & 3.20 & 12.20 \\
\hline $11(200 \mu \mathrm{M})$ & 26.80 & 3.15 & 29.95 \\
\hline
\end{tabular}

Table IV. Pro-apoptotic activity of isoxazole derivatives 1-11 in T98G cells.

\begin{tabular}{|c|c|c|c|}
\hline Samples & Early apoptosis,\% & Late apoptosis, $\%$ & Total apoptosis, $\%$ \\
\hline Untreated cells (-) & 6.95 & 2.25 & 9.20 \\
\hline $1(50 \mathrm{nM})$ & 3.63 & 2.46 & 6.09 \\
\hline $1(100 \mathrm{nM})$ & 4.83 & 8.44 & 13.27 \\
\hline $2(10 \mathrm{nM})$ & 4.65 & 2.56 & 7.21 \\
\hline $2(20 \mathrm{nM})$ & 2.35 & 2.57 & 4.92 \\
\hline $3(50 \mathrm{nM})$ & 32.60 & 7.90 & 40.50 \\
\hline $3(100 \mathrm{nM})$ & 37.50 & 11.00 & 48.50 \\
\hline $4(100 \mathrm{nM})$ & 32.55 & 6.25 & 38.80 \\
\hline $4(200 \mathrm{nM})$ & 36.20 & 10.60 & 46.80 \\
\hline $5(50 \mathrm{nM})$ & 29.30 & 3.85 & 33.15 \\
\hline $5(100 \mathrm{nM})$ & 34.05 & 8.65 & 42.70 \\
\hline $6(50 \mathrm{nM})$ & 15.50 & 1.65 & 17.15 \\
\hline $6(100 \mathrm{nM})$ & 13.30 & 3.95 & 17.25 \\
\hline $7(1 \mu \mathrm{M})$ & 6.90 & 2.30 & 9.20 \\
\hline $7(5 \mu \mathrm{M})$ & 13.60 & 3.15 & 16.75 \\
\hline $8(5 \mu \mathrm{M})$ & 8.55 & 2.20 & 10.75 \\
\hline $8(10 \mu \mathrm{M})$ & 13.65 & 5.45 & 19.10 \\
\hline $9(1 \mu \mathrm{M})$ & 28.15 & 13.65 & 41.80 \\
\hline $9(5 \mu \mathrm{M})$ & 36.95 & 11.95 & 48.90 \\
\hline $10(50 \mu \mathrm{M})$ & 9.20 & 3.35 & 12.55 \\
\hline $10(100 \mu \mathrm{M})$ & 17.75 & 8.65 & 26.40 \\
\hline $11(100 \mu \mathrm{M})$ & 6.10 & 1.85 & 7.95 \\
\hline $11(200 \mu \mathrm{M})$ & 12.35 & 3.15 & 15.50 \\
\hline
\end{tabular}


A

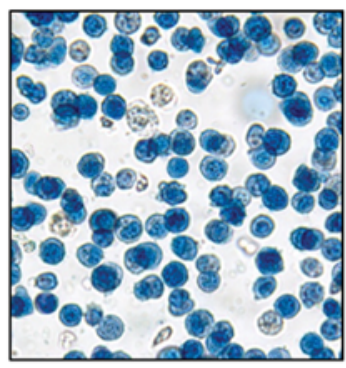

B

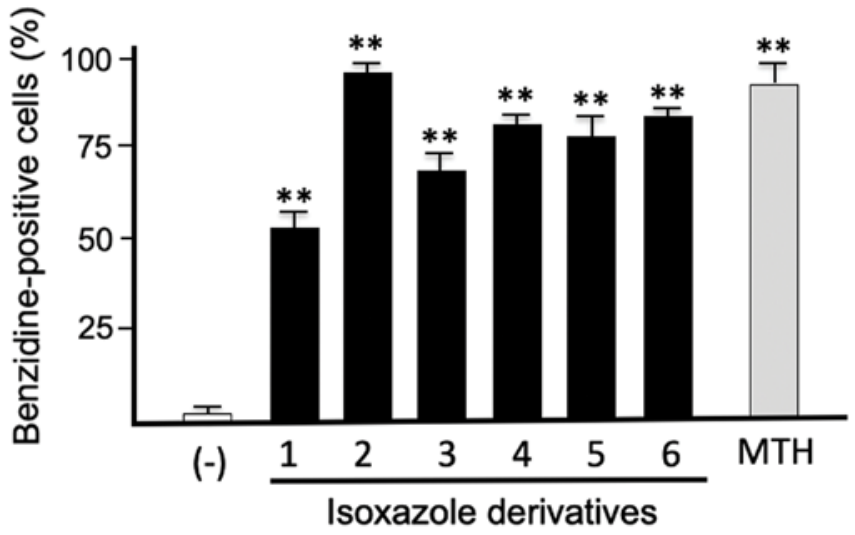

Figure 7. Effects of synthetic isoxazole derivatives on erythroid differentiation of K562 cells. (A) Example of benzidine-positive K562 cells induced by compound 2 (blue cells). Magnification, x40. (B) Percentage of induction of erythroid differentiation (\% of benzidine-positive cells) in K562 cells treated with isoxazole derivatives and MTH $(30 \mathrm{nM})$ used as positive control. Results are presented as the mean $\pm \mathrm{SEM}(\mathrm{n}=3)$. ${ }^{* *} \mathrm{P}<0.01 \mathrm{vs}$. control untreated cells. (-), control untreated cells; MTH, mithramycin.

known agents (such as mithramycin, MTH), K562 cells respond within few days activating the terminal stages of differentiation, associated with increased production of embryo-fetal hemoglobins (mainly $\mathrm{Hb}$ Gower 1 and $\mathrm{Hb}$ Portland). As several antitumor compounds exert their action through activation of differentiated functions $(26,27)$, erythroid differentiation was analyzed in K562 cells treated with compounds exhibiting the highest inhibitory effects on cell growth (the isoxazoles 1, 2, 3, 4, 5 and 6; Table I) and studied by determining the proportion of blue benzidine-positive (hemoglobin containing) cells. This enzymatic-colorimetric test was performed after 7 days of cell culture. Blue cells were counted and the obtained data expressed in percentage of benzidine positive cells (Fig. 7). ANOVA confirmed that the isoxazole derivatives 1-6 possessed a high capability in inducing differentiation in the K562 cells $(\mathrm{P}<0.0001)$. For all the compounds, very high significance was found when comparison was performed with control untreated cells (Dunnett's test $\mathrm{P}<0.0001$ for all compounds). Among the tested compounds, compound 2 exhibited the highest efficiency in inducing erythroid differentiation in respect to the other compounds (Tukey's test $\mathrm{P}$-values were: $\mathrm{P}<0.0002$ when comparison was performed for compounds 1 and 3 , and $\mathrm{P}=0.0046, \mathrm{P}=0.0467$ and $\mathrm{P}=0.0022$ when comparison was performed with 4,5 and 6 . The compounds 4,5 and 6 possessed the same capability in inducing differentiation in the K562 cells.

\section{Discussion}

Most types of human cancer share common hallmarks, including self-sufficiency in growth signals, insensitivity to growth-inhibitory mechanism leading to unrestricted cell proliferation, evasion of programmed cell death, sustained angiogenesis, tissue invasion and metastasis (28). Heat shock protein 90 (HSP90) is a molecular chaperone protein involved in the conformational maturation, stability and function of so-called 'client' proteins. It has been proved that HSP90 is a key regulator protein of tumor cell cycle progression where it is overexpressed $(29,30)$. This upregulation may be an adaptive response by cancer cells to maintain protein homeostasis and promote cell survival in an unfavorable environment as well as to stimulate cell proliferation and inhibit cell death. The ability to attach carrier molecules direct to specific tumors have a potential for the development into selective anticancer agents avoiding toxic side effects on normal healthy tissues. Thus, the interest of HSP90 as possible anticancer targets and for throughput screening is getting high.

Natural compounds as geldanamycin and radicicol are the pioneering compounds capable to inhibit this class of proteins, nevertheless it was necessary to modify their chemical structure because both of them exhibit several issues as poor solubility, significant hepatotoxicity, intrinsic chemical instability altering in vivo activity. For these reasons we generated novel synthetic HSP90 inhibitors (4,5,6,7-Tetrahydro-isoxazolo-[4,5-c]-pyridines and 3,4-Isoxazolediamide derivatives) in order to increase the efficiency. We have elsewhere reported that these analogues are very powerful in inhibiting HSP90, even when used at concentrations lower than geldanamycin and radicicol; furthermore, geldanamycin and radicicol are known to exhibit low solubility and cause in vivo unwanted side effects, such as hepatotoxicity (31). Finally, this study envisages the possible use of inhibitors of HSP-90 in searching for analogues exhibiting high level of antiproliferative and pro-apoptotic activities.

The general aim of this study was to determine the biological activity of these new isoxazole compounds on tumor cell lines.

An antiproliferative effect on K562 cells was observed for the analogues 1-7 and 9, that exhibited cytotoxic effect at nanomolar concentrations. Another compound that exhibited lower but significant antiproliferative effect was compound 8 , characterized by a $3.2 \pm 1.1 \mu \mathrm{M} \mathrm{IC}_{50}$ value. Compounds 10 and 11 were able to induce antiproliferative effect on K562 cells only when added at high concentrations $\left(\mathrm{IC}_{50}\right.$ values $>60 \mu \mathrm{M}$ ), while 12 and 13 were completely inactive at the used concentrations $\left(\mathrm{IC}_{50}>300 \mu \mathrm{M}\right)$. Further, the differentiation was analyzed in $\mathrm{K} 562$ cells treated with the compounds exhibiting the highest antiproliferative activity by 
determining the proportion of benzidine-positive cells after 6 days of treatment. Compounds 1-6 were found to stimulate erythroid differentiation (especially compound 2) at very high level, inducing very high percentages of benzidine-positive cells $(98 \%, 50 \mathrm{nM}$, in the case of compound $2 ; 74-82 \%$ in the case of compounds 4, 5 and 8).

In this context, this study is limited, due to the fact that few tumor cell lines were analyzed (the human erythroleukemic K562 cell line, as a representative model for tumor cell growing in suspension and the two glioma U251-MG and T98G cell lines, growing attached to the flask). While other cancer cell lines and further in vivo experiments should be considered, the results of the present study about the in vitro cell growth are encouraging. A second limitation is that in this study the issue of combined antitumor therapy was not addressed. In any case, considering the interesting inhibitory effects on the growth of the TMZ-resistant T98G cells, the use of the molecules here described could be combined with treatments based on drugs already employed in conventional therapy (such as chemotherapy) of glioblastoma, and might be of interest in the treatment of patients not-responsive to TMZ.

A second conclusion of our study is that the antiproliferative effects of the analyze compounds is the activation of apoptosis. The possible pro-apoptotic effects of these HSP90 inhibitors was investigated on K562 cells and on two additional cell lines representative of neuronal solid tumors, i.e the gliolastoma U251-MG and T98G cells. It should be noted that glioblastoma multiforme (VI grade tumor) is one of the most aggressive solid tumors and the TMZ-based chemotherapy, while remaining the most commonly used treatment, cannot be considered efficient in TMZ resistant gliomas. In this respect, the resistance to antitumor compounds is the most important problem in the clinical management of these patients, leading to low survival. Therefore, in our investigation the effects on the U251-MG cell line and on the TMZ-resistant T98G cell line were also compared.

All the tested derivatives were used at two concentrations that always included those demonstrated to cause 50\% inhibition of in vitro cell growth. Interestingly all compounds were found to possess the ability to induce apoptosis on K562 cells, especially the isoxazoles $4,7,8,9$ and 11 , shown to exhibit high levels pro-apoptotic activity $(>50 \%)$. In fact, the derivatives $4(100 \mathrm{nM}), 8(10 \mu \mathrm{M})$ and $11(200 \mu \mathrm{M})$ displayed very high level of apoptotic effect $(80.10,90.60$ and $88.50 \%$, respectively). More in detail, the common feature observed is that the early apoptosis stage was always higher than the later one in presence of each compound, with the exception of the derivative 1 .

As far as the apoptosis analysis performed also on U251-MG and T98G glioma cell lines using the compounds $1-11$, the derivatives $2,3,4,5$ and 11 exhibited the best activity, showing total apoptosis values $\geq 30 \%$; the top levels of apoptosis were observed when the TMZ-resistant T98G cells were treated with the isoxazoles 3, 4, 5 and 9 (total apoptosis $>40 \%$ ).

As far as apoptosis, this manuscript is limited to the fact that only a FACS approach has been employed to investigate apoptosis (i.e. the Annexin V and the Caspase 3/7 kit assays). A number of assays (i.e. ELISA for histone/DNA fragment, poly-ADP-ribose-polymerase cleavage assay, and terminal deoxynucleotidyl transferase-mediated dUTP nick-end-labeling assay) (32) should be also considered in order to fully characterized the induction of the apoptotic phenotype. Furthermore, the study of apoptosis-related molecular markers (for instance, but not limited to, p53, BAX, Bcl2, pro-apoptotic miRNAs) (33) will be useful in the future to elucidate the activity of the investigated isoxazole derivatives on specific targets.

In summary, despite the above-mentioned limitations, this study supports the concept that isoxazole derivatives here described are active in inhibiting tumor cell growth in vitro, are able to induce apoptosis. Furthermore, all of them are potent inducers of erythroid differentiation when the erythroleukemic K562 cell system was employed. Therefore, the most effective compound here described deserve further consideration in testing their activity as antitumor drugs using in vivo assays based on mouse tumor model systems.

\section{Acknowledgements}

The authors would like to thank Professor Giulio Cabrini (Department of Neurosciences, Biomedicine and Movement, University of Verona, Verona, Italy) for providing useful discussion on the effects of the studied compounds on glioma cell lines.

\section{Funding}

The present study was supported by Associazione Italiana per la Ricerca sul Cancro (AIRC) (IG \#13575; to RG) and by Fondo per le Agevolazioni alla Ricerca (Lampronti-2018; to IL). This study was also supported by the Interuniversity Consortium for the Biotechnology (project no. 40/18), Italy.

\section{Availability of data and materials}

The datasets used and/or analyzed during the current study are available from the corresponding author on reasonable request.

\section{Authors' contributions}

DS, RR and RB designed and synthesized the compounds. IL, $\mathrm{AF}, \mathrm{MB}, \mathrm{CT}$ and RG designed and performed the experiments, analyzed and the interpreted data. IL and RG wrote the paper. CS applied statistical algorithms to the obtained results. All authors agree to be accountable for all aspects of the research in ensuring that the accuracy or integrity of any part of the work are appropriately investigated and resolved. All authors read and approved the final manuscript.

\section{Ethics approval and consent to participate}

Not applicable.

\section{Patient consent for publication}

Not applicable.

\section{Competing interests}

The authors declare that they have no competing interests. 


\section{References}

1. Macario AJ and Conway de Macario E: Sick chaperones, cellular stress, and disease. N Engl J Med 353: 1489-1501, 2005.

2. Powers MV and Workman P: Inhibitors of the heat shock response: Biology and pharmacology. FEBS Lett 581: 3758-3769, 2007.

3. Garcia-Carbonero R, Carnero A and Paz-Ares L: Inhibition of HSP90 molecular chaperones: Moving into the clinic. Lancet Oncol 14: e358-e369, 2013

4. Welch WJ: The role of heat-shock proteins as molecular chaperones. Curr Opin Cell Biol 3: 1033-1038, 1991.

5. Rowlands MG, Newbatt YM, Prodromou C, Pearl LH, Workman $\mathrm{P}$ and Aherne W: High-throughput screening assay for inhibitors of heat-shock protein 90 ATPase activity. Anal Biochem 327: 176-183, 2004.

6. Cragg GM and Newman DJ: Plants as a source of anti-cancer agents. J Ethnopharmacol 100: 72-79, 2005.

7. Whitesell L, Mimnaugh EG, De Costa B, Myers CE and Neckers LM: Inhibition of heat shock protein HSP90-pp60v-src heteroprotein complex formation by benzoquinone ansamycins: Essential role for stress proteins in oncogenic transformation. Proc Natl Acad Sci USA 91: 8324-8328, 1994

8. Sauville E: Heat shock protein-90 directed therapeutics and target validation. In: Cancer Drugs Design and Discovery, Elsevier, Amsterdam, Netherlands. pp 336-350, 2008

9. Sharma SV, Agatsuma T and Nakano H: Targeting of the protein chaperone, HSP90, by the transformation suppressing agent, radicicol. Oncogene 16: 2639-2645, 1998.

10. Lia Y, Zhanga D, Xu J, Shia J, Jiang L, Yaoa N and Ye W: Discovery and development of natural heat shock protein 90 inhibitors in cancer treatment. Acta Pharm Sin B 2: 238-245, 2012.

11. Brough PA, Aherne W, Barril X, Borgognoni J, Boxall K, Cansfield JE, Cheung KM, Collins I, Davies NG, Drysdale MJ, et al: 4,5-diarylisoxazole Hsp90 chaperone inhibitors: Potential therapeutic agents for the treatment of cancer. J Med Chem 51 196-218, 2008

12. Baruchello R, Simoni D, Grisolia G, Barbato G, Marchetti P, Rondanin R, Mangiola S, Giannini G, Brunetti T, Alloatti D, et al: Novel 3,4-isoxazolediamides as potent inhibitors of chaperone heat shock protein 90. J Med Chem 54: 8592-8604, 2011.

13. Baruchello R, Simoni D, Marchetti P, Rondanin R, Mangiola S, Costantini C, Meli M, Giannini G, Vesci L, Carollo V, et al: 4,5,6,7-Tetrahydro-isoxazolo-[4,5-c]-pyridines as a new class of cytotoxic Hsp90 inhibitors. Eur J Med Chem 76: 53-60, 2014

14. Biamonte MA, Van de Water R, Arndt JW, Scannevin RH, Perret D and Lee WC: Heat shock protein 90: Inhibitors in clinical trials. J Med Chem 53: 3-17, 2010.

15. Taldone T, Sun W and Chiosis G: Discovery and development of heat shock protein 90 inhibitors. Bioorg Med Chem 17: 2225-2235, 2009.

16. Khan MT, Lampronti I, Martello D, Bianchi N, Jabbar S, Choudhuri MS, Datta BK and Gambari R: Identification of pyrogallol as an antiproliferative compound present in extracts from the medicinal plant Emblica officinalis: Effects on in vitro cell growth of human tumor cell lines. Int J Oncol 21: 187-192, 2002.

17. Bianchi N, Ongaro F, Chiarabelli C, Gualandi L, Mischiati C, Bergamini $\mathrm{P}$ and Gambari R: Induction of erythroid differentiation of human K562 cells by cisplatin analogs. Biochem Pharmacol 60: 31-40, 2000.

18. Brognara E, Fabbri E, Bazzoli E, Montagner G, Ghimenton C, Eccher A, Cantù C, Manicardi A, Bianchi N, Finotti A, et al Uptake by human glioma cell lines and biological effects of a peptide-nucleic acids targeting miR-221. J Neurooncol 118 : 19-28, 2014.
19. Lozzio CB and Lozzio BB: Human chronic myelogenous leukemia cell-line with positive Philadelphia chromosome. Blood 45: 321-334, 1975

20. Lampronti I, Khan MTH, Borgatti M, Bianchi N and Gambari R: Inhibitory Effects of Bangladeshi Medicinal Plant Extracts on Interactions between Transcription Factors and Target DNA Sequences. Evid Based Complement Alternat Med 5: 303-312, 2008.

21. Brognara E, Fabbri E, Montagner G, Gasparello J, Manicardi A, Corradini R, Bianchi N, Finotti A, Breveglieri G, Borgatti M, et al: High levels of apoptosis are induced in human glioma cell lines by co-administration of peptide nucleic acids targeting miR-221 and miR-222. Int J Oncol 48: 1029-1038, 2016.

22. Lampronti I, Borgatti M, Vertuani S, Manfredini S and Gambari R: Modulation of the expression of the pro-inflammatory IL-8 gene in cystic fibrosiscells by extracts deriving from olive mill waste water. Evid Based Complement Alternat Med 2013: 960603, 2013.

23. Finotti A, Bianchi N, Fabbri E, Borgatti M, Breveglieri G, Gasparello J and Gambari R: Erythroid induction of K562 cells treated with mithramycin is associated with inhibition of raptor gene transcription and mammalian target of rapamycin complex 1 (mTORC1) functions. Pharmacol Res 91: 57-68, 2015.

24. Fibach E, Prus E, Bianchi N,Zuccato C, Breveglieri G, Salvatori F, Finotti A, Lipucci di Paola M, Brognara E, Lampronti I, et al: Resveratrol: Antioxidant activity and induction of fetal hemoglobin in erythroid cells from normal donors and $\beta$-thalassemia patients. Int J Mol Med 29: 974-982, 2012.

25. Scabini M, Stellari F, Cappella P, Rizzitano S, Texido G and Pesenti E: In vivo imaging of early stage apoptosis by measuring real-time caspase-3/7 activation. Apoptosis 16: 198-207, 2011.

26. Bianchi N, Chiarabelli C, Borgatti M, Mischiati C, Fibach E and Gambari R: Accumulation of gamma-globin mRNA and induction of erythroid differentiation after treatment of human leukaemic K562 cells with tallimustine. Br J Haematol 113: 951-961, 2001.

27. Mischiati C, Sereni A, Lampronti I, Bianchi N, Borgatti M, Prus E, Fibach E and Gambari R: Rapamycin-mediated induction of gamma-globin mRNA accumulation in human erythroid cells. Br J Haematol 126: 612-621, 2004

28. Workman P: Pharmacogenomics in cancer drug discovery and development: Inhibitors of the Hsp90 molecular chaperone. Cancer Detect Prev 26: 405-410, 2002.

29. Schopf FH, Biebl MM and Buchner J: The HSP90 chaperone machinery. Nat Rev Mol Cell Biol 18: 345-360, 2017

30. McDonald E, Workman P and Jones K: Inhibitors of the HSP90 molecular chaperone: Attacking the master regulator in cancer. Curr Top Med Chem 6: 1091-1107, 2006.

31. Gorska M, Popowska U, Sielicka-Dudzin A, Kuban-Jankowska A, Sawczuk W, Knap N, Cicero G and Wozniak F: Geldanamycin and its derivatives as Hsp90 inhibitors. Front Biosci 17: 2269-2277, 2012 .

32. Ward TH, Cummings J, Dean E, Greystoke A, Hou JM, Backen A, Ranson M and Dive C: Biomarkers of apoptosis. Br J Cancer 99: 841-846, 2008.

33. Gerl R and Vaux DL: Apoptosis in the development and treatment of cancer. Carcinogenesis 26: 263-270, 2005.

This work is licensed under a Creative Commons Attribution-NonCommercial-NoDerivatives 4.0 International (CC BY-NC-ND 4.0) License. 